Makale türü / Article type: Araştırma / Research

\title{
Küreselleşme Sürecinde Geliş̧mekte olan Ülkelerde Dış Borçların İktisadi Kalkınma Üzerindeki Etkisi: Heterojen Panel Yaklaşımı
}

****

\section{The Effect of External Debt on Economic Development in Developing Countries in the Process of Globalization: Heterogeneous Panel Approach}

\author{
Öğr. Gör. Hikmet Akyol \\ Gümüşhane Üniversitesi, Şiran Mustafa Beyaz Meslek Yüksekokulu \\ hikmetakyol76@gmail.com \\ (ORCID:0000-0001-9119-7416) \\ Öğr. Gör. Kübra Karakuş \\ Muş Alparslan Üniversitesi, Sosyal Bilimler Meslek Yüksekokulu \\ k.karakus@alparslan.edu.tr \\ (ORCID:0000-0001-9845-0082) \\ Özet
}

$\mathrm{Bu}$ araştırmada NIC olarak tanımlanan Brezilya, Çin, Hindistan, Endonezya, Malezya, Meksika, Filipinler, Güney Afrika, Tayland ve Türkiye'de dış borçlar ve iktisadi büyüme arasındaki kısa ve uzun dönem ilişki, ekonomik küreselleşme süreci içerisinde incelenmiştir. Aynı zamanda, bu ülkelerde dış borçlanmanın iktisadi büyümeyi hangi yönden etkilediği tespit edilmeye çalışılmıştır. Araştırmada, NIC ülkelerinin 1995-2015 dönemi heterojen panel veri analizi yöntemi ile analiz edilmiş̧ir. Gengenbach (2016), eşbütünleşme ve AMG testi bulgularına göre, Brezilya, Hindistan, Endonezya, Malezya ve Güney Afrika ile Tayland'da dış borçlar uzun dönemde iktisadi büyümeyi negatif etkilemiştir. Çin, Meksika, Filipinler ve Türkiye'de ise uzun dönemde dış borçların iktisadi büyüme üzerinde anlamlı herhangi bir nedensellik etkisi yoktur.

Anahtar Kelimeler: Dış Borç, İktisadi Büyüme, Küreselleşme, NIC Ülkeleri. Jel Sinıflandırması: F63, H60, H63.

\begin{abstract}
In this research, the NIC defined as Brazil, China, India, Indonesia, Malaysia, Mexico, Philippines, South Africa, Thailand and Turkey between external debt and economic growth in the short-and long-term relationship, were investigated in the process of economic globalization. At the same time, it has been tried to determine in which way external debt affects economic growth in these countries. In the research, the period
\end{abstract}


1995-2015 of NIC countries was analyzed by heterogeneous panel data analysis method. According to gengenbach (2016), co-integration and AMG test findings, external debts in Brazil, India, Indonesia, Malaysia and South Africa and Thailand have negatively affected economic growth in the long term. In China, Mexico, the Philippines and Turkey, external debt has no significant causal effect on economic growth in the long term.

Key Words: External Debt, Economic Growth, Globalization, NIC Countries. Jel Classification: F63, H60, H63.

\section{GİRİ̧̧}

Borçlanma, kamu kesiminin finansman ihtiyacını temin etmek amacıyla başvurulan yollardan biridir. Devlet, borçlanma ihtiyacını ülke içindeki ve ülke dışındaki kaynaklardan karşılayabilir. Bu anlamda dış borç; Bir ülkenin diğer ülkelerden ya da finans kuruluşlarından sağlamış olduğu döviz cinsinden bir sermaye olarak açıklanmaktadır (Akan ve Kanca, 2015, s.3). Hükümetlerin veya ülke otoritelerinin dışardan borçlanmalarının tarihi çok eski dönemlere dayanmaktadır. Özellikle 20. yüzyıl öncesinde birçok ülkenin artan savaş maliyetlerini karşılayabilmek amacıyla dışardan borçlanmaya gittikleri görülmektedir. 1970'li yıllardan itibaren ise dünya genelinde yaşanan deregülasyon hareketlerinin artması ve sermaye zengini gelişmiş ülkelerden sermaye ve tasarruf sıkıntısı çeken gelişmekte olan ülkelere doğru fon akımlarının artması dış borçlanma konusuna yeni bir boyut kazandırmıştır. Ülkeler özellikle büyük alt yapı yatırımlarını gerçekleştirmek, sürdürülebilir bir iktisadi büyümeyi yakalamak, çeşitli fon ihtiyaçlarını karşılamak ve döviz sıkıntılarını gidermek amacıyla dış borçlanmaya çok sık başvurmaktadırlar. Buradaki en temel mesele sağlanan dış borçların etkin bir şekilde kullanılıp kullanılmadığıdır. Zira dışardan sağlanan finansman üretim kapasitesini artırmak için kullanılmayıp bütçe açıkları ve cari harcamaların giderilmesi için kullanılırsa kaynak israfına yol açmasının yanında söz konusu borcun geri ödenmesini de zorlaştırır (Kutlu ve Yurttagüler, 2016, s.230). Özellikle geçmiş yıllarda kontrolsüz/yönetilemez dış borçların ülkelere olan maliyetlerinin çok ağır olduğu görülmüştür. Örneğin, 1979' da yaşanan ikinci petrol krizi sonrasında 1980-1983 arasında görülen ekonomik durgunluk, dış borç servisi fazla olan ülkeleri kötü etkilemiş ve bu ülkelerin reel milli 
gelirlerinde ciddi düşüşler olmuştur (Esener, 2013, s.21). Yine 1991'de Sovyetler Birliği'nin çöküşünden sonra ortaya çıkan geçiş ekonomilerinde diş borçlanmanın etkin alanlarda kullanılmak yerine ithalatın karşılanmasında kullanılması (bilhassa tüketim malları) bu ekonomilerin bir bölümünde dış borç sorununu önemli ölçüde arttırmıştır (Uzun vd., 2012, s.151).

Ekonomik ve doğal kaynakların eşit dağılmaması, ülkeler arasındaki gelişmişlik farkları, küreselleşme olgusu, değişen uluslararası ilişkiler gibi nedenlerden dolayı birçok ülkenin öz kaynakları, kalkınmalarında yetersiz kalmış, özellikle gelişmekte olan ülkelerde iktisadi büyümenin sağlanabilmesi için gerekli yatırımların mevcut kaynaklardan karşılanamaması borçlanma gereksinimini arttırmıştır (Işsk, 2017, s.118). Dış borçlanmanın ülke ekonomileri üzerinde bazı makroekonomik etkileri söz konusudur. Bu etkiler ülkelerin bulunduğu sosyo-ekonomik şartlara göre farklılık göstermektedir. $\mathrm{Bu}$ kapsamda örneğin ülke ekonomileri özelinde alınan dış borçların ekonomik büyüme üzerinde etkisi, faiz oranlarına ve ödünç alınan yabancı kaynakların etkin kullanılıp kullanılmamasına göre değişiklik göstermektedir. Eğer alınan borç verimli alanlarda kullanılırsa büyüme ivme kazanır. Ancak dış borçlar faiz oranı yüksek olan yatırımlara yönlendirilirse büyüme hızı yavaşlayacaktır (Lin ve Sosin, 2001, s. 636-638).

$\mathrm{Bu}$ araştırmada Brezilya, Çin, Hindistan, Endonezya, Malezya, Meksika, Filipinler, Güney Afrika, Tayland ve Türkiye'nin (NIC) dış borç birikimleriyle iktisadi büyümeleri arasındaki kısa ve uzun dönem ilişkisi, ekonomik küreselleşme sürecine bağlı olarak incelenmiştir. NIC ülkeleri ya da daha geniş bir ifadeyle yeni sanayileşen ülkeler terimi, ekonomik anlamda gelişmiş bir ülke yapısına sahip olmayan, fakat makroekonomik anlamda hızlı ekonomik ve sosyal kalkınma düzeyleri ile öteki gelişmekte olan ülkelerden ayrılan ekonomiler için kullanılır (Wikipedia, 2019). NIC ülkeleri, dış dünya ile ekonomik anlamda yoğun bir ilişki içerisinde olan ve sürdürülebilir bir iktisadi kalkınmayı gerçekleştirmek için dış borçlanmaya önem veren ülkeler olarak görülebilir. Bu bakımdan bu ülkelerin dış dünya ile olan ekonomik bütünleşme düzeylerinin artmasına bağlı olarak artan dış borç birikimlerinin, onların iktisadi büyümelerini nasıl etkilediğinin tespit edilmesi çok önemlidir. Aynı zamanda, bu ülkelerde dış borçlanmanın iktisadi büyümeyi hangi 
yönden etkilediği tespit edilmeye çalışılmıştır. Buna bağlı olarak dış borç ve iktisadi büyüme arasındaki ilişkinin ülkelere göre nasıl farklılaştığı görülmek istenmiştir. NIC ülkelerinin dış borç birikimleri ile iktisadi büyümeleri arasında bir benzerlik bulunup bulunmadığının görülmesi, politika yapıcıları ve araştırmacılar açısından önemli imalar içermektedir. Araştırmanın bir diğer amacı ise uygulanan analizler sonucunda elde edilecek bulguların ampirik ve torik çalışmalar ile uygunluk gösterip göstermediğinin ortaya konması ve böylece literatüre katkı sağlanmasıdır.

Ekonomik küreselleşme süreci içerisinde dış borç ve iktisadi büyüme ilişkisi heterojen panel veri yaklaşımı ile analiz edilmiştir. Araştırmanın söz konusu amaçları ve bu amaçların yerine getirilmesinde kullanılan ekonometrik yöntem, onu literatürdeki birçok çalışmadan ayrıştırarak, özgünleştirmiştir. Zira, literatür incelendiğinde ekonomik küreselleşme sürecine bağlı olarak, dış borçların iktisadi büyüme ile olan ilişkisini inceleyen çalışmaların çok sınırlı olduğu görülmüştür. Aynı zamanda, söz konusu ilişkiyi heterojenliği göz önünde bulundurarak ampirik ve teorik bakımdan inceleyen çalışmalara ise rastlanılmamıştır.

Araştırma altı bölümden oluşmuştur. Birinci bölüm olan giriş kısmında araştırmanın konusu, önemi ve amacından bahsedilmiştir. İkinci bölüm olan kavramsal çerçeve kısmında ise değişkenler arasındaki teorik ilişki açıklanmıştır. Üçüncü bölüm olan literatür taraması kısmında literatürde yapılmış benzer çalışmalar verilmiştir. Dördüncü bölüm olan ekonometrik yöntem ve veri kısmında, araştırmada kullanılan ekonometrik yöntem ve veriler tanıtılmıştır. Beşinci bölüm olan analiz ve uygulamalar bölümünde ise uygulanan ekonometrik yöntem ve testler sonucunda elde edilen bulgular verilmiştir. Son bölüm olan sonuç kısmında analiz bulguları irdelenmiş ve literatürdeki diğer ampirik ve teorik çalışmalar ile kıyaslama yapılarak değerlendirmede bulunulmuştur.

\section{KAVRAMSAL ÇERÇEVE}

Dış borçlar ve iktisadi büyüme arasındaki ilişki makroekonomik açıdan çok önemlidir. $\mathrm{Bu}$ bakımdan geçmişten günümüze değin, bu iki faktör arasındaki ilişkinin teorik ve ampirik yönleri yoğun bir şekilde incelenmiştir. 
Klasikler, devletin savaş ve olağanüstü imar işleri dışında borçlanmasına karş1 çıkmışlar, alınan borçların kar getirmeyen alanlarda kullanılacağı için kamunun iflas edebilme riskini buna gerekçe göstermişlerdir (Çoban, 2008, s.246). Keynesyenler ise bunun tam tersini savunarak, iktisadi büyümeyi canlı k1lmada devlet müdahalesinin esas olduğunu ileri sürmüşlerdir (Kara, 2001, s.96). Keynes'e göre, depresyon ve işsizliğin kaynağında talep eksikliği vardır ki, bu problemin dış borçlanma yoluyla finanse edilecek kamu harcamalarıyla giderilmesi gerekir (Nalesco, 2012, s.11). Dış borçların iktisadi büyümeyi olumlu etkilediğini savunan ve Keynesyen ekolün devamı niteliğindeki bir diğer yaklaşım ise Harrod-Domar Modelidir. Bu modelde üretim seviyesi yatırım oranlarına ve bu yatırımlardaki üretkenliğe bağlı olup, bu yatırımlar tasarruflar tarafindan karşılanmaktadır; bu modele göre dişa açık bir ekonomide toplam tasarruflar, yurtiçi tasarruflar ve yurtdışı tasarrufların toplamına eşittir (Hijertholm vd., 1998, s.3). Mosley vd. (1987), çalışmalarında Harrod-Domar modelinin büyüme üzerinde üç farklı etkisi olduğunu ileri sürmüştür: Birincisi, dış kaynakların (borç/yardım) ${ }^{1}$ direkt yatırımlara nominal olarak tahsis edilmesi sonucunda ortaya çıkan direkt etkidir. İkincisi, borcu alan ülkenin kamu harcamalarına olan etkisidir. Üçüncüsü ise kamu politikalarının tamamına olan dolaylı etkileridir.

Keynesyenlerin aksine Neoklasik yaklaşım ise dış borçların iktisadi büyümeyi olumsuz etkilediğini savunmuştur. Diamond (1965), dış borçların uzun dönemde iktisadi büyüme üzerinde iki farklı etkisi olduğunu savunmuştur. Buna göre, söz konusu etkiler faiz ödemelerini finanse etmek için başvurulan vergilerden kaynaklanmaktadır. Birinci olarak, vergiler ömür boyu tüketimi (vergi ödeyenlerin) doğrudan etkileyerek azaltmakta, ikincisi olarak ise harcanabilir geliri azaltarak, vergi tasarruflarını ve dolaysıyla sermaye stokunu azaltmaktadir (Diamond, 1965, s.1126). Duran (2017)'in ifade ettiği gibi, Neoklasik model uzun dönem için geçerliyken, Keynesyen modeller kısa dönemi kapsamaktadır. Kısa dönemde fiyatların katı olduğu göz önünde bulundurulursa, kamunun borçlanması mal ve hizmete olan talebi

\footnotetext{
${ }^{1}$ Mosley vd. (1987), çalışmalarında dış yardım ve büyüme ilişkisini incelemiştir. Dolaysıyla, Harrod-Domar modelinin etkilerini açıklarken, dış yardımın büyüme üzerindeki etkileri şeklinde ele almışlardır.
} 
arttırarak, tüketim ve gelir düzeyini, sonuç olarak ise büyümeyi arttırabilir; Buna karşın, dışlama etkisi (crowding-out) ve borç fazlası (the overhang effect) yoluyla diş borçlanma iktisadi büyümeyi olumsuz etkileyebilir (Duran, 2017, s.267-268). Dış borçların iktisadi büyümeyi olumsuz etkilediğini savunan borç fazlası teorisi Krugman (1988), Sachs (1989) ve Cohen (1993), tarafından geliştirilmiştir. Bu yaklaşım, 1980'lerde orta gelirli ve özel borç verenler ile anlaşma imzalayan ülkeleri kapsayan Latin Amerika krizi sonrasında geliştirilmesine karşın, piyasaya erişimi kısıtlı ve koşullu dış borca son derece bağımlı, düşük gelirli Sahra-Altı Afrika ülkelerini de kapsayacak şekilde genişletilmiştir (Presbitero, 2008, s.2). Krugman (1988), belirsizlikler altında bir ülkenin sağladığı dış kaynak, onun yükümlülüklerini tam olarak yerine getirmesine yetmiyorsa, borç verenlerin davranışlarının ve ülkenin ekonomik ikliminin bundan olumsuz etkileneceğini savunmuştur. Buna göre, bir ülkenin borç stoku gelecekte geri ödeme gücünü aşması durumunda, beklenen borç servisi söz konusu ülkenin hâsıla düzeyinin artan bir fonksiyonu olur ve ülke ekonomisindeki yatırımlar yabancı borç verenler tarafından vergilendirileceği için yerli/yabancı yatırımcıların yatırım yapma güdüleri azalır (Bilginoğlu ve Aysu, 2008, s.7). Bu durum ise iktisadi büyümeyi olumsuz etkileyecektir. Panizza ve Presbitero (2014), k1sa dönemde etkili olsa dahi, dış borç seviyesini arttıran genişletici maliye politikalarının uzun dönemli büyümeyi azaltabileceğini ve bu nedenle mali teşviklerin olumlu etkilerini kısmen ya da tamamen ortadan kaldırabileceğini savunmuştur. Aşırı borçlanma modelleri, dış borçların iktisadi büyüme üzerindeki etkilerini açık bir biçimde analiz etmese de büyük çaplı dış borç stoklarının (birikim) yatırım oranlarını gerileterek, büyümeyi düşüreceğini ima eder (Pattilo vd., 2002, s.33). Dış borç birikimi ile iktisadi büyüme arasındaki ilişki, dış borçların belli bir düzeyin üstüne çıktı̆̆ı zaman büyümeyi negatif yönlü etkilediği, bir zil çanına benzetilebilir (Presbitero, 2008, s.3). Buna göre, dış borçlar belli bir düzeye gelinceye kadar büyümeyi özendirirken, söz konusu düzeyin üstüne çıtığında iktisadi büyümeyi olumsuz etkilemektedir. Örneğin, kalkınma aşamasının başında yer alan ve düşük sermaye birikimine sahip gelişmekte olan ülkelerde dış borçlanma belli bir noktaya/düzeye kadar iktisadi büyümeyi pozitif etkileyebilir (Pattillo vd., 2002, s.33). Fakat, dış borç birikiminin sürdürülebilir bir noktanın üstüne 
çıkması durumunda, borçların zamanında ödenememesi ve/veya artan borçların ödenmesi için vergi artışlarına ya da başka yatırımcıların huzurunu bozacak önlemlere başvurulması sonucunda dış borçların büyüme üzerindeki etkisi negatif yönlü olacaktır. Ekonomik teoride bu yaklaşım Borç Laffer Ĕ̆risi ile açıklanmıştır. Borç Laffer eğrisinde yukarı yönlü eğime sahip kısım (iyi) dış borcun geri ödenme olasılığının yüksek olduğunu gösterirken, aşağı eğimli (kötü) kısım, dış borcun geri ödenme olasılığının düşük olduğunu göstermektedir (Pattillo vd., 2002, s.33).

Dış borçlar ile iktisadi büyüme arasındaki ilişkiyi inceleyen bir diğer teorik yaklaşım ise Easterly (1999), zamanlararası borçlanma/borç verme modelidir. Bu model, zamanlararası tüketim optimizasyonu teorisinin bir devamıdır (Bilginoğlu ve Aysu, 2008, s.4). Easterly (1999), modelinde değişmeyen uzun dönemli tasarruf tercihlerine sahip ülkelerin borç ertelemesini (hafifletmesini) sağlamak adına, tekrar borçlanacağını ya da bu durama varlıklarını tüketerek karşılık vereceğini öngörmüştür. Zamanlararası borçlanma/borç verme modeline göre, aşırı borçlu bir ülke geleceğe karşı yüksek iskonto oranına sahip bir ülkedir ve / veya zamanlararası düşük zamanlararası esnekliğine sahiptir (Nissanke ve Ferrarini, 2001, s.1). Easterly (1999), aşırı borç yüküne sahip düşük gelirli ülkeler (HIPC) üzerine yoğunlaştığı modelinde, yüksek iskonto oranlarına sahip hükümetlerin zayıf (kötü) politikalar tercih edeceğini ve bunun ise tüm ekonominin zamanlararası tercihini etkileyeceğini öngörmüştür. Easterly, HPIC'lerin aşırı borcunu, ülke varlıklarının tükenme eğilimi sergilediği, zamanlararası tercihlerin kendine özgü bir yansıması olarak görmüştür (Nissanke ve Ferrarini, 2001, s.1).

\section{LITERATÜR TARAMASI}

Dış borçlar ile iktisadi büyüme arasındaki ilişki 1980’lerin başındaki küresel krizden sonra literatürde ciddi bir şekilde incelenmiştir (Adamu ve Rasiah, 2016, s.291). Bu araştırmalar HIPC üzerine yoğunlaşmıştır (Bilginoğlu ve Aysu, 2008:12). Gunter (2002) belirttiği gibi 1980 ve 1990 yılları arasında az gelişmiş ülkelerin toplam dış borç stokları hızlı bir şekilde 125 milyar dolardan 419 milyar dolara çıkmıştır. Buna karşılık gayri safi milli hasılaları (GSMH) ise 1.3 trilyon dolardan 900 milyar dolara gerilemiştir. Başka bir ifadeyle bu ülkelerin dış borçlarının GSYH'ye oranları 1990' da ise 
\%31'den fazla artmıştır (Gunter, 2002, s.5). Az gelişmiş ülkelerin dış borç stoklarının çok yüksek ve sürdürülemez oluşu geçmiş y1llarda bu ülkelerde önemli ekonomik sorunlara neden olmuştur.

Bilginoğlu ve Aysu (2008) 1965-2008 dönemini ve Türkiye'yi kapsayan araştırmalarında dış borçlar ile ekonomik büyüme arasındaki ilişkiyi regresyon analizi kullanarak (EKK) incelemişlerdir. Araştırmada kullanılan değişkenler GSMH, sabit sermaye yatırımları, nüfus artış hızı, toplam dış borç stokunun GSMH içindeki payı, Millî Eğitim Bakanlığı ile Yükseköğretim kurumlarının konsolide bütçe içerisindeki payı ve ihracat ile ithalat toplamının GSMH içindeki payıdır. Araştırma bulgularına göre dış borçların ekonomik büyüme üzerinde negatif yönlü bir etkisi söz konusudur. Araştırmacılar, söz konusu bulgu üzerinden Türkiye'nin borç fazlası problemi olan bir z olduğunu ileri sürmüştür.

Reinhart ve Rogoff (2010), 44 gelişmiş ve gelişmekte olan ülkede iki yüzyılı aşkın bir süre için (1790-2009), çeşitli dönem aralıklarıyla merkezi hükümet borcu, büyüme ve enflasyon arasındaki ilişkiyi incelemiştir. Merkezi hükümet borcu/GSYH, GSYH ve enflasyon araştırmada kullanılan değişkenlerdir. Araştırma bulgularına göre, yüksek düzeyli borçların düşük seyreden büyüme ile ilişkili olduğu (negatif yönlü ilişki) tespit edilmiştir.

Butts vd. (2012), 1970-2003 döneminde Tayland'da iktisadi büyüme ve kısa dönemli dış borçlar arasındaki ilişkiyi ARDL sınır testi yaklaşımı kullanarak incelemiştir. Araştırmada kullanılan değişkenler kısa vadeli dış borçlar, GSYH, döviz kuru ve uluslararası rezervlerdir. Araştırma sonuçlarına göre, dış borçlar ile iktisadi büyüme arasında pozitif yönlü bir ilişki vardır. Bunun yanı sıra, iktisadi büyümeden dış borçlara doğru dolaylı Granger nedensellik olduğu tespit edilmiştir.

Uzun vd. (2012), 1993-2007 dönemi ile geçiş ekonomilerini inceledikleri araştırmalarında dış borç ve ekonomi büyüme arasındaki ilişkiyi panel veri analizleri kullanarak incelenmişlerdir. GSYH, dış borçların ihracata oranı ve dışa açıklık araştırmada kullanılan değişkenlerdir. Araştırma sonuçlarına göre, dış borçlar ile iktisadi büyüme arasında pozitif yönlü bir ilişki vardır. Araştırmacılara göre, söz konusu bulgu, araştırma ülkelerinin hala borç Laffer eğrisinin pozitif eğim kısmında olduklarını göstermektedir. 
Gül vd. (2012) 1994-2010 döneminde Orta Asya Cumhuriyetleri ve Türkiye için dış borcun ekonomik büyüme üzerindeki etkisini incelemiştir. Araştırmada panel eşbütünleşme ve panel nedensellik testleri uygulanmış, dış borç servisi ile GSYH değişkenleri kullanılmıştır. Araştırma bulgularına göre uzun dönemde diş borçlardan ekonomik büyümeye doğru tek taraflı bir nedensellik vardır. Kısa dönemde ise değişkenler arasında herhangi bir nedensellik ilişkisi tespit edilmemiştir. Araştırmacılar, söz konusu bulguyu Türk Cumhuriyetleri’nin bağımsızlıklarını kazandıktan sonra artan dış borç yüküne bağlamıştır.

Kasidi ve Said (2013), 1990-2010 dönemini ve Tanzanya’yı kapsayan araştırmalarında dış borç stoku ve dış borç servisinin iktisadi büyüme ile olan ilişkisini regresyon analizleri ve Johansen eşbütünleşme testini kullanarak incelemiştir. Araştırmada kullanılan değişkenler GSYH, dış borç servisi ve dış borç stokudur. Araştırma sonuçlarına göre, değişkenlerin iktisadi büyüme üzerinde anlamlı etkisi vardır. Analiz bulguları, toplam dış borç stokunun yaklaşık 0.36939 oranında büyümeyi pozitif etkilediğini, buna karşın borç servisinin yaklaşık 28.517 oranında büyümeyi negatif yönlü etkilediğini göstermiştir. Eşbütünleşme test bulguları ise değişkenler arasında herhangi bir ilişki bulunmadığını ortaya koymuştur.

Moore ve Thomas (2013), 17 bağımsız çalışmadan 62 gözlem derleyerek kullandıkları meta-regresyon analizleri yardımıyla HIPC ülkelerinde dış borçların iktisadi büyümenin finansmanında kullanılıp kullanılmadığını araştırmışlardır. Çok sayıda meta-bağımsız değişkenin kullanıldığı araştırma sonuçlarına göre, dış borçlar iktisadi büyüme ile pozitif yönlü bir ilişki içerisindedir.

Zouhaier ve Fatma (2014), 1990-2011 döneminde 19 gelişmekte olan ülkenin dış borç ve iktisadi büyüme ilişkisini ölçmek için panel veri analizi uygulamıştır. Araştırmada kişi başına düşen GSYH, enflasyon, yatırım oranları, dışa açıklık, toplam dış borcun GSYH'ye oranı, dış borç stokunun GSMH'ye oranı, kamu ve özel kesim garantili borçlar, kısa dönem borçlar ve toplam diş borçlardaki değişimler kullanılan değişkenlerdir. Araştırma sonuçlarına göre, dış borçlar iktisadi büyümeyi negatif yönlü etkilemektedir. 
Akram (2015), 1975-2010 döneminde Philipinler'de dış borç ve iktisadi büyüme ilişkisini ARDL sınır testi yaklaşımı kullanarak incelemiştir. Araştırmada kullanılan değişkenler yatırımların GSYH'ye oranı, dış dengenin GSYH'ye oranı, dış borç stokunun GSYH'ye oranı, bütçe açığının GSYH'ye oranı, dış borç servisinin ihracata oranı, enflasyon ve işsizlik oranlarıdır. Araştırma bulgularına göre iktisadi büyüme ve dış borç arasında negatif yönlü bir ilişki bulunmaktadır. Araştırmacı, söz konusu bulgunun borç fazlası (aşırı borçlanma) teorisini doğruladığını savunmuştur.

Eberhardt ve Presbitero (2015), 1961-2012 döneminde 118 ülkede iktisadi büyüme ve diş borç ilişkisini doğrusal/doğrusal olmayan yönden ve heterojenlik üzerinden incelemişlerdir. Doğrusal dinamik modellerin kullanıldığ1 araştırmada, kullanılan değişkenler GSYH, sermaye stoku ve toplam dış borç stokudur. Analiz sonuçları, iktisadi büyüme ve dış borçlar arasında negatif yönlü bir ilişki bulunduğuna dair kimi kanıtları gösterse de bunun ülkeler için benzerlik içerdiğine dair bir bulguyu göstermemektedir.

Gürdal ve Yavuz (2015), 1990-2013 dönemini ve Türkiye'yi kapsayan araştırmalarında diş borçlanma ve iktisadi büyüme ilişkisini Gregory-Hansen Eşbütünleşme, Hacker ve Hatemi-J nedensellik testleri uygulayarak incelemiştir. Araştırmada kullanılan değişkenler, sanayi üretim endeksi ve dış borç stokudur. Araştırma sonuçlarına göre, değişkenler arasında eşbütünleşme ilişsisi bulunmaktadır. Aynı zamanda, iktisadi büyümeden dış borca doğru tek yönlü nedensellik tespit edilmiştir.

Bittencourt (2015), 1970-2007 dönemini ve Güney Amerika'nın genç demokrasilerinde kamunun ve diş borçların belirleyicilerini dinamik panel veri analizi kullanarak incelemiştir. Kamu borcunun GSYH'ye oranı, dış borç stokunun GSYH'ye oranı, GSYH büyümesi, ticari açıklık, enflasyon, nüfus, kentleşme oranları, kamu payının GSYH’ye oranı ve gelir eşitsizliğidir. Araştırma sonuçlarına göre, bu ülkelerde görülen iktisadi büyüme oranları borç oranlarını önemli ölçüde azaltmaktadır (negatif yönlü ilişki).

Khemais vd. (2016) 1961-2011 dönemini ve Tunus ekonomisini kapsayan araştırmasında, dış borç ve iktisadi büyüme arasındaki ilişkiyi Var yaklaşımı kullanarak incelemiştir. Araştırmada kullanılan değişkenler, GSYH, ödenmemiş borcun GSYH'ye oranı ve mal ve hizmet ihracatıyla iliş̧kili borç servisidir. Araştırma sonuçlarına göre, kısa dönemde mal ve 
hizmet ihracatıyla ilişkili borç servisi ve ödenmemiş borç değişkeni iktisadi büyümenin nedeni değildir. Buna karşın, uzun dönemde dış borç servisi Tunus ekonomisine zarar vermektedir (negatif yönlü ilişki).

Donayre ve Taivan (2017), 20 OECD ülkesini ve 1970-2009 dönemini kanonik eşbütünleşme, VAR ve Granger temelli analizler yardımıyla incelemiştir. GSYH büyüme oranları, kamu borcunun GSYH oranı, ticaretin GSYH'ye oranı ve brüt sermaye oluşumunun GSYH'ye oranı kullanılan değişkenlerdir. Araştırmada, modern refah devletlerinin kamu borcundaki artışları takiben düşük reel büyüme yaşadığ1, daha geleneksel refah devletlerinin ve daha büyük hükümetlere sahip olanların ise tipik olarak düşük büyümeden borç birikimine doğru tek yönlü veya çift yönlü nedensellik gösterdiği tespit edilmiştir.

Duran (2017), 1986-2015 döneminde Filipinler'i Johansen eşbütünleşme, VECM ve Granger nedensellik testleri uygulayarak incelemiştir. GSYH, iç borç stoku ve diş borç stoku araştırma kapsamında kullanılan değişkenlerdir. Araştırmada, iktisadi büyüme ile iç ve dış borçlar arasında uzun dönem ilişkisi bulunduğu tespit edilmiştir. Buna göre söz konusu dönemde, dış borçların iktisadi büyüme üzerinde pozitif yönlü etkisi tespit edilirken, iç borçlanmanın büyüme üzerinde negatif yönlü etkisi tespit edilmiştir.

Mohamed (2018), 1969-2015 döneminde ve Sudan'da dış borçların iktisadi büyüme üzerindeki etkisini Johansen eşbütünleşme ve VECM testleri uygulayarak incelemiştir. Araştırma sonuçlarına göre, değişkenler arasında uzun dönemli ilişkisi vardır. GSYH, dış borçların ihracata oranı, nominal döviz kurları ve doğrudan yabancı sermaye yatırımları (DYSY) araştırma kapsamında kullanılan değişkenlerdir. VECM bulgularına göre ise dış borçların büyüme üzerinde pozitif yönlü etkisi varken döviz kurları ve DYSY'lerin iktisadi büyüme üzerinde negatif yönlü etkisi vardır.

Guei (2019), 13 gelişmekte olan ülkede 1990-2016 dönemini panel ARDL yaklaşımı kullanarak incelenmiştir. GSYH, dış borçların GSYH'ye oranı, faiz dışı bütçe dengesi ve borçların faiz ödemesi ile enflasyon oranlarıdır. Araştırma sonuçlarına göre, uzun dönemde dış borçların iktisadi 
büyüme üzerinde herhangi bir etkisi tespit edilmezken, kısa dönemde negatif yönlü etkisi vardır.

Morabhe (2019), Tanzanya'da ve 1970-2015 döneminde dış borç ve iktisadi büyüme ilişkisini EKK regresyon analizleri, Johansen eşbütünleşme ve Granger nedensellik testleri kullanarak incelemiştir. Araştırmada kullanılan değişkenler GSYH, dış borç stoku ve dış borç servisidir. Araştırma sonuçlarına göre, dış borçlar ile iktisadi büyüme arasında pozitif yönlü ilişki vardır. Johansen eşbütünleşme ve Granger nedensellik test bulgularına göre ise değişkenler arasında uzun dönem ve nedensellik ilişkisi bulunmaktadır.

\section{EKONOMETRİK YÖNTEM VE VERİ}

$\mathrm{Bu}$ bölümde araştırmanın kapsamı, kullanılan yöntem ve veriler hakkında gerekli bilgiler verilmektedir. Başka bir ifadeyle, araştırmada kullanılan ülke grubu ve döneme ilişkin bilgilerin yanı sıra, araştırmada kullanılan yöntem ve veri seti ile ilgili bilgi verilmiştir.

\subsection{Ekonometrik Yöntem}

$\mathrm{Bu}$ araştırmada yeni sanayileşen ülkelerin (NIC), diş borç birikimlerinin (stoku) iktisadi büyüme üzerindeki kısa ve uzun dönem etkisi ekonomik küreselleşme sürecine bağl1 bir şekilde incelenmektedir. Başka bir ifadeyle, dış borçların iktisadi büyüme olan ilişkisinin küreselleşme konjonktüründe teorik ve ampirik açıdan nasıl geliştiği analiz edilmektedir. NIC ülkeleri, Brezilya, Çin, Hindistan, Endonezya, Malezya, Meksika, Filipinler, Güney Afrika, Tayland ve Türkiye'den oluşmaktadır. Bu ülkeler, ekonomik anlamda her ne kadar gelişmiş ülke yapısına sahip olmasalar dahi, dinamik ve hızlı gelişen yapılarıyla diğer gelişmekte olan ülkelerden ayrışmaktadır. Araştırmada ikinci olarak, dış borçlar ve iktisadi büyüme arasındaki ilişkinin hangi teorik yaklaşımlar ile uyumlu olduğu incelenmektedir. Bunun yanı sıra, değişkenler arasındaki ilişkinin ülkelere göre farklılaşıp farklılaşmadığı sorgulanmaktadır.

$\mathrm{Bu}$ araştırmada dış borç stoku ile iktisadi büyüme arasındaki ilişki heterojen panel analizi yaklaşımları ile sınanmaktadır. Araştırmada panel veri analizinin tercih edilmesinin temel nedeni, bu yaklaşımın zaman serilerine ve yatay kesit testlerine kıyasla daha karmaşık ve geniş kapsamlı sonuçların 
ortaya koyulmasına olanak tanımasıdır. Aynı zamanda birden fazla ülke grubuyla çalışıldığı için panel veri analizi birimler bazında etkinin görülmesi açısından uygun bir yaklaşımdır.

\subsubsection{Yatay Kesit Bağımııı̆ı ve Panel Birim Kök Testlerine İlişkin Yöntem}

Değişkenler arasındaki ilişkinin tahminine yönelik model test edilmeden önce serilerin durağanlıkları sınanmaktadır. Zira birim kök içeren seriler ile tahmin edilen modellerde sahte regresyon riski çok yüksektir. Serilerin durağanlıklarını inceleyen birim kök testleri ise kendi aralarında birinci ve ikinci kuşak panel birim kök testleri olmak üzere iki gruba ayrılmıştır. Birinci kuşak panel birim kök testleri birimler arası korelasyonu dikkate almazken ikinci kuşak panel birim kök testleri bu sorunu hesaplamalarda dikkate almaktadır. Araştırma kapsamında değişkenlerin birimler arası korelasyon sorunu içerip içermediği Pesaran (2004) CD, Breusch Pagan LM, Pesaran Scaled LM ve Önyargıl1-Düzeltilmiş LM testleri ile sınanmaktadır. Test bulgularına göre her üç değişkende de yatay kesit bağımlılı̆g bulunmaktadır. Bu doğrultuda serilerin durağanlıkları ikinci kuşak panel birim kök testlerinden yatay kesit genişletilmiş Im, Pesaran ve Shin (CIPS) testi ve birimler arası korelasyonu dikkate alacak şekilde geliştirilmiş Im, Pesaran ve Shin (IPS) ile Maddala ve Wu (1999) Fisher Genişletilmiş Dickey Fuller (Fisher ADF) testleri ile sinanmaktadır.

\subsubsection{Eşbütünleşme Testleri ve Uzun Dönemin Tahminine İlişkin Yöntem}

Düzey değerlerinde durağan olmayan seriler arasındaki ilişkiyi eşbütünleşme testleri ile sınamak mümkündür. Eşbütünleşme testleri kalıntı temelli ya da hata düzeltme modelli temelli testlerdir. Bu testlerde kendi aralarında birimler arası korelasyonu dikkate almayan ve dikkate alan birinci ve ikinci kuşak testler olmak üzere ikiye ayrılmaktadır. Bu araştırmada uygun eşbütünleşme testini belirlemek amacıyla kurulan modellerin birimler arası korelasyon sorunu taşıyıp taşımadığı Pesaran ve Smith MG tahmincisi üzerinden Pesaran (2015) CD testi ile sinanmaktadır. Test bulgularına göre 
modelde birimler arası korelasyon sorunu bulunmaktadır. Bu bakımdan araştırmada değişkenler arasındaki eşbütünleşme ilişkisi ikinci kuşak panel eşbütünleşme testlerinden Gengenbach vd. (2016) testi ile sinanmaktadır. Gengenbach vd. (2016) eşbütünleşme testi heterojenlik, dengesiz paneller ve birimlerde eşit olmayan gecikme uzunluklarına olanak tanımaktadır (Tatoğlu, 2017:207).

Durağan olmayan seriler arasındaki eşbütünleşme ilişkisinin saptanması halinde değişkenler arasındaki eşbütünleşme ilişkisine ait uzun dönem katsayılarını tahmin etmek mümkündür. $\mathrm{Bu}$ araştırmada değişkenler arasındaki uzun dönem katsayılarının tahmini birimler arası korelasyonu ve heterojenliği dikkate alan Bond ve Eberhardt (2009) ile Eberhardt ve Teal (2010) genişletilmiş ortalama Grup (AMG) tahmincileri ile sinanmaktadır. AMG panel hata düzeltme modeli değişkenler arasındaki kısa ve uzun dönem ilişkilerini birlikte ele almaktadır. Araştırmada modellerin sabit ve eğim parametrelerinin homojen/heterojen olup olmadığı Swamy $\mathrm{S}$ testi ile sinanmaktadır.

\subsection{Veri}

$\mathrm{Bu}$ araştırmada reel GSYH (Amerikan Doları) ve diş borç stoku (GSMH'ye oranı) Dünya Bankası'ndan temin edilmiştir. Ekonomik küreselleşme verileri ise KOF İsviçre Ekonomi Enstitüsü'nden temin edilmiştir. Ülkelerin küresel düzeyde, diğer ülkeler ile ekonomik bütünleşme düzeyini göster KOF ekonomik küreselleşme endeksi, fiili olarak mal ve hizmet ticareti ile ticari partner çeşitliliğinden oluşurken, yasal olarak ticaret düzenlemeleri ve vergileri, tarifeler ile antlaşmalardan oluşmaktadır. Modelde yer alan değişkenlere ilişkin açıklamalar Tablo 1'de verilmiştir.

Tablo 1. Araştırma Değişkenleri

\begin{tabular}{lll}
\hline Değişken & Açıklaması & Veri Türü \\
\hline LN(GSYH) & $\begin{array}{l}\text { Reel GSYH'nin logaritması } \\
\text { alınmıştır }\end{array}$ & Amerikan Doları \\
DBSTOK & $\begin{array}{l}\text { Dış Borç Stoku } \\
\text { E. Küreselleşme değerinin } \\
\text { logaritması alınmışır }\end{array}$ & GSMH'ye oranı \\
LN(KOFEC $)$ & & \\
\hline
\end{tabular}


Araştırmanın aynı zamanda hipotezlerini temsil eden modeli ise aşağıdaki gibi tanımlanmıştır:

$$
L N(G S Y H))_{i t}=\alpha_{0}+\beta_{1} \text { DBSTOK }{ }_{i t+} \beta_{2} L N(\text { KOFEC })_{i t}+\varepsilon_{i t}
$$

Burada $G S Y H$, iktisadi büyümeyi temsil etmektedir. DBSTOK, diş borç stokunu ve KOFEC ise ekonomik küreselleşme düzeyini temsil etmektedir. GSYH ve $K O F E C$ değişkenlerinin logaritmik dönüşümleri yapılmıştır.

\section{ANALIZ VE BULGULAR}

$\mathrm{Bu}$ bölümde araştırmada uygulanan testler ve bunun sonucunda elde edilen bulgular verilmiştir. Tablo 2'de araştırma değişkenlerine ilişkin korelasyon matrisi verilmiştir. Korelasyon matrisi incelendiğinde değişkenler arasındaki korelasyon ilişkisinin kabul edilebilir sınırlar içerisinde olduğu görülmüştür.

Tablo 2. Korelasyon Matrisi

\begin{tabular}{llll}
\hline & LN(GSYH) & DBSTOK & LN(KOFEC) \\
\hline LN(GSYH) & $\mathbf{1 . 0 0 0 0}$ & & \\
DBSTOK & -0.5166 & $\mathbf{1 . 0 0 0 0}$ & \\
LN(KOFEC) & -0.5701 & 0.5444 & $\mathbf{1 . 0 0 0 0}$ \\
\hline
\end{tabular}

Tablo 3'te değişkenlere ilişkin betimsel istatistikler ve açıklayıcı değişkenler arasında çoklu doğrusallık problemi bulunup bulunmadığını gösteren varyans artış faktörü (VIF) değerleri verilmiştir. VIF değerlerine göre değişkenler arasında çoklu doğrusallık problemi bulunmamaktadır.

Tablo 3. Betimsel İstatistikler ve VIF Testi

\begin{tabular}{llll}
\hline & LN(GSYH) & DBSTOK & LN(KOFEC) \\
\hline Gözlem & 210 & 210 & 210 \\
\hline
\end{tabular}




\begin{tabular}{llll}
\hline Ortalama & 27.15155 & 35.79929 & 3.856415 \\
S. Sapma & 1.001128 & 20.69167 & .264908 \\
Min. & 25.37926 & 8.28788 & 2.923608 \\
Max. & 29.818 & 168.1778 & 4.26488 \\
VIF & 1.42 & 1.42 \\
VIF Ort. & & & 1.42 \\
\hline
\end{tabular}

\subsection{Yatay Kesit ve Panel Birim Kök Test Bulguları}

Yatay kesit bağımlığı ve panel birim kök test bulguları Tablo 4'te verilmiştir. Yatay kesit bağımlılı̆̆ test bulgularına göre her üç değişken için de birimler arası korelasyon sorunu geçerlidir. $\mathrm{Bu}$ bakımdan serilerin durağanlıkları ikinci kuşak panel birim kök testleri (IPS, CIPS ve Fisher ADF) ile sınanmıştır. Test bulgularına göre değişkenler düzey değerlerinde birim kök içermektedir. Ancak serilerin farkı alındığında değişkenler durağanlaşmaktadır. $\mathrm{Bu}$ bakımdan değişkenler arasındaki uzun dönem ilişkisini eşbütünleşme testleri ile sınamak mümkündür.

Tablo 4. YKB ve Panel Birim Kök Testleri

\begin{tabular}{lllllll}
\hline \multicolumn{3}{l}{ LN(GSYH ) } & \multicolumn{3}{l}{ DBSTOK } & \multicolumn{2}{l}{ LN(KOFEC) } \\
\hline & $\mathbf{I}[\mathbf{0}]$ & $\mathbf{I}[\mathbf{1}]$ & $\mathbf{I}[\mathbf{0}]$ & $\mathbf{I}[\mathbf{1}]$ & $\mathbf{I}[\mathbf{0}]$ & $\mathbf{I}[\mathbf{1}]$ \\
$\mathbf{I P S}$ & 2.4889 & $-7.2990 \mathrm{a}$ & 0.5569 & $-8.8855 \mathrm{a}$ & -0.9552 & $-8.4650^{\mathrm{a}}$ \\
CIPS & -1.392 & $-2.661^{\mathrm{a}}$ & -1.675 & $-3.353 \mathrm{a}$ & $-2.134 \mathrm{c}$ & $-4.688^{\mathrm{a}}$ \\
Fisher & 21.9822 & $85.4148 \mathrm{a}$ & 13.6834 & $102.3625^{\mathrm{a}}$ & 26.9278 & $54.5788^{\mathrm{a}}$ \\
ADF & 1.6054 & $-5.0457 \mathrm{a}$ & 0.7799 & $-7.5963 \mathrm{a}$ & -1.1246 & $-4.4522^{\mathrm{a}}$ \\
& 1.9708 & $-7.0439 \mathrm{a}$ & 0.8096 & $-8.9767 \mathrm{a}$ & -1.1661 & $-4.5207^{\mathrm{a}}$ \\
& 0.3134 & $10.3435 \mathrm{a}$ & -0.9987 & $13.0227^{\mathrm{a}}$ & 1.0954 & $5.4674^{\mathrm{a}}$ \\
& & & $177.9349^{\mathrm{a}}$ & & $282.7061^{\mathrm{a}}$ & \\
BP LM & $909.9417^{\mathrm{a}}$ & & $14.01257^{\mathrm{a}}$ & & $25.05643^{\mathrm{a}}$ & \\
Pes. S.LM & $91.17286^{\mathrm{a}}$ & & & & & \\
\hline
\end{tabular}




\begin{tabular}{llll}
\hline Ö-D. LM & $90.92286^{\mathrm{a}}$ & $13.76257^{\mathrm{a}}$ & $24.80643^{\mathrm{a}}$ \\
Pes. CD & $30.16222^{\mathrm{a}}$ & $7.238039^{\mathrm{a}}$ & $8.398899^{\mathrm{a}}$
\end{tabular}

a, b ve c sırasıyla $\% 1, \% 5$ ve $\% 10$ anlamlılı̆̆ temsil etmektedir.

\subsection{Gengenbach vd. (2016) ile AMG Test Bulguları}

Araştırmada değişkenler arasında kurulan modelin birimler arası korelasyon sorunu taşıyıp taşımadığı daha önce de ifade edildiği üzere Pesaran ve Smith MG tahmincisi üzerinden Pesaran (2015) CD testi ile sınanmıştır. Test bulgularına göre kurulan modelde birimler arası korelasyon sorunu bulunmaktadır. Aynı zamanda uzun dönem parametrelerinin heterojenliği Swamy S testi ile sınanmıştır. Test bulguları Tablo 5'te verilmiştir. Tablo incelendiğinde kurulun modelin uzun dönem parametrelerinin heterojen olduğu görülmüştür. Dolaysıyla değişkenler arasındaki eşbütünleşme ilişkisi Gengenbach vd. (2016) testi ile uzun dönem katsayıları ise heterojen AMG yaklaşımı ile sınanmıştır. Test bulguları Tablo 6'da verilmiştir. Tablo incelendiğinde DBSTOK ve LN(KOFEC) ile LN(GSYH) arasında \%99 güven düzeyinde eşbütünleşme ilişkisi bulunduğu tespit edilmiştir.

Tablo 5. Pesaran (2015) ve Swamy Test Bulguları

\begin{tabular}{ll}
\hline Testler & Model \\
\hline Swamy S Testi $\left(\chi^{2}\right)$ & $270.72(\mathrm{p}<=0.001)$ \\
Pesaran (2015) CD Testi & $6.431(\mathrm{p}<=0.001)$ \\
\hline
\end{tabular}

AMG hata düzeltme modeli bulgularına göre uzun dönem hata parametresi (-0.31) anlamlı ve negatiftir. Buna göre kısa dönemde meydana gelen dengesizlik \%30 bir sonraki dönemde düzelmektedir. Başka bir ifadeyle değişkenlerin durağan olmamasından kaynaklanan dalgalanmalar yaklaşı üç y1l sonra ortadan kalkmaktadır. DBSTOK değişkeninin LN(GSYH) üzerinde kısa ve uzun dönemde negatif etki söz konusudur. LN(KOFEC) değişkenin ise uzun dönemde $\mathrm{LN}(\mathrm{GSYH})$ üzerinde pozitif ve anlamlı bir etkisi söz 
konusuyken, kısa dönemde aralarında herhangi bir nedensellik ilişkisi olmadığ1 görülmüştür.

Tablo 6. Gengenbach vd. (2016) ve AMG Test Bulguları

\begin{tabular}{|c|c|c|c|}
\hline & \multicolumn{3}{|c|}{ Gengenbach vd. (2016) Testi } \\
\hline & Katsayısı & T-bar & Prob. \\
\hline \multirow[t]{3}{*}{ ECT(-1) } & -0.539 & -3.083 & $\mathrm{p}<=0.01$ \\
\hline & \multicolumn{3}{|c|}{ AMG Hata Düzeltme Modeli } \\
\hline & Katsayısı & Z-İstatistik & Prob. \\
\hline ECT(-1) & $\begin{array}{l}-.3140255 \\
(.0794114)\end{array}$ & -3.95 & $0.0000^{\mathrm{a}}$ \\
\hline DBSTOK & $\begin{array}{l}-.00030554 \\
(.0013067)\end{array}$ & -2.34 & $0.019^{\mathrm{a}}$ \\
\hline$\Delta($ DBSTOK $)$ & $\begin{array}{l}-.0021403 \\
(.0010362)\end{array}$ & -2.07 & $0.039^{b}$ \\
\hline LN(KOFEC) & $\begin{array}{l}.0877762 \\
(.052943)\end{array}$ & 1.66 & $0.097^{\mathrm{c}}$ \\
\hline$\Delta(\mathbf{L N}[$ KOFEC $])$ & $\begin{array}{l}-.0432519 \\
(.0748118)\end{array}$ & -0.58 & 0.563 \\
\hline
\end{tabular}

a, b ve c sirasıyla $\% 1, \% 5$ ve $\% 10$ anlamlılı̆ğ temsil etmektedir. 
Ülkeler bazında Brezilya, Hindistan, Endonezya, Malezya ve Güney Afrika ile Tayland'da DBSTOK uzun dönemde LN(GSYH)'i negatif etkilemektedir. Çin, Meksika, Filipinler ve Türkiye'de ise uzun dönemde DBSTOK'un LN(GSYH) üzerinde anlamlı herhangi bir nedensellik etkisi bulunmamıştır. Uzun dönemde LN(KOFEC) değişkeni LN(GSYH) üzerinde Brezilya, Çin, Hindistan ve Güney Afrika'da pozitif etkiye sahiptir. Ancak Endonezya, Malezya, Meksika, Filipinler ve Tayland ile Türkiye'de iki değişken arasında uzun dönemde herhangi bir nedensellik ilişkisi tespit edilmemiştir.

Tablo 7. AMG Modeli Ülke Katsayılarına İlişkin Bulgular

\begin{tabular}{|c|c|c|c|}
\hline & \multicolumn{2}{|c|}{ DBSTOK } & \multirow[t]{2}{*}{ LN(KOFEC) } \\
\hline & ECT(-1) & SR & \\
\hline \multirow[t]{2}{*}{ Brezilya } & $-.0018448^{\mathrm{a}}$ & $-.0021149^{a}$ & $.1793616^{\mathrm{a}}$ \\
\hline & $(.0003959)$ & $(.0008821)$ & $(.0505789)$ \\
\hline \multirow[t]{2}{*}{ Çin } & -.0022378 & .0011619 & $.1471449^{a}$ \\
\hline & $(.002701)$ & $(.0024323)$ & $(.0477452)$ \\
\hline \multirow[t]{2}{*}{ Hindistan } & $-.0144407^{\mathrm{a}}$ & $-.0108454^{\mathrm{a}}$ & $-.1828592^{c}$ \\
\hline & $(.005565)$ & $(.003817)$ & $(.1036651)$ \\
\hline \multirow[t]{2}{*}{ Endonezya } & $-.0004474^{\mathrm{b}}$ & $-.0017683^{\mathrm{a}}$ & -.0364995 \\
\hline & $(.0002347)$ & $(.0001534)$ & $(.0397525)$ \\
\hline \multirow[t]{2}{*}{ Malezya } & $-.0026408^{\mathrm{a}}$ & -.0010212 & .3731332 \\
\hline & $(.0007495)$ & $(.0009488)$ & (.415999) \\
\hline \multirow[t]{2}{*}{ Meksika } & -.0019473 & -.0014204 & .2763357 \\
\hline & $(.0015092)$ & $(.0018737)$ & $(.270746)$ \\
\hline
\end{tabular}




\begin{tabular}{llll}
\hline Filipinler & .00039 & .0003065 & -.0541242 \\
& $(.0004879)$ & $(.0009263)$ & $(.112288)$ \\
Güney Afrika & $-.00308^{\mathrm{a}}$ & $-.0015947^{\mathrm{b}}$ & $.149324^{\mathrm{a}}$ \\
& $(.0009322)$ & $(.0005586)$ & $(.042808)$ \\
Tayland & $-.0024723^{\mathrm{a}}$ & $-.0015947^{\mathrm{b}}$ & .0440685 \\
& $(.0004736)$ & $(.0007801)$ & $(.1460947)$ \\
Türkiye & -.0018328 & $-.0029876^{\mathrm{a}}$ & -.0107309 \\
& $(.0012321)$ & $(.0011995)$ & $(.2356401)$ \\
\hline
\end{tabular}

a, b ve c sırasıly $\% 1, \% 5$ ve $\% 10$ anlamlılı̆g temsil etmektedir.

DBSTOK kısa dönemde Brezilya, Hindistan, Endonezya, Güney Afrika, Tayland ve Türkiye'de LN(GSYH) üzerinde negatif yönlü etkiye sahiptir. Çin, Malezya, Meksika ve Filipinler'de ise kısa dönemde DBSTOK'un LN(GSYH) ile aralarında anlamlı herhangi bir nedensellik etkisi tespit edilmemiştir.

\section{SONUÇ}

$\mathrm{Bu}$ araştırmada NIC ülkelerinde dış borçların iktisadi büyüme ile arasındaki kısa ve uzun dönem ilişkisi ekonomik küreselleşme sürecine bağlı bir biçimde incelenmiştir. Başka bir ifadeyle, ekonomik küreselleşme sürecinin dış borç ve iktisadi büyüme arasındaki ilişkiyi ülkeler açısından nasıl şekillendirdiği ölçülmüştür. Bunun yanı sıra, değişkenler arasındaki ilişkinin araştırma ülkelerine göre farklılaşıp farklılaşmadığı sorgulanmıştır.

Araştırma bulgularına göre, uzun dönemde NIC ülkelerinin dış borç birikimi ve ekonomik küreselleşme düzeyleri ile iktisadi büyümeleri arasında uzun dönem ilişkisi vardır. Buna göre, dış borç stokunda meydana gelen artış, NIC ülkelerinde iktisadi büyümeyi negatif yönlü etkilemiştir. Bu bulgu, teorik olarak dış borçlarda yaşanan artışların büyümeyi olumsuz etkileyeceğini öne süren borç fazlası yaklaşımını doğrulamaktadır. Buna karşın, uzun dönemde ekonomik küreselleşme düzeyi NIC ülkelerinin iktisadi büyümelerini pozitif 
yönlü etkilemiştir. Buna göre, ekonomik küreselleşme düzeyi arttıkça NIC ülkelerinin iktisadi kalkınması bundan olumlu etkilenmiştir. Ülkeler bazında incelendiğinde Brezilya, Hindistan, Endonezya, Malezya ve Güney Afrika ile Tayland'da dış borçlar uzun dönemde iktisadi büyümeyi negatif yönlü etkilemiştir. Bu bulgular, dış borçların iktisadi büyümeyi olumsuz etkilediğini savunan borç fazlası (aşırı borçlanma) teorisini ve bu yönde bulgular ortaya koyan ampirik çalışmaları doğrulamaktadır. Çin, Meksika, Filipinler ve Türkiye'de ise dış borçların iktisadi büyüme üzerinde anlamlı bir etkisi tespit edilmemiştir. Ancak ileride yapılacak araştırmalar bu ülkelerde dış borçlar ve iktisadi büyüme arasındaki ilişkiyi daha açık bir şekilde ortaya koyması bakımından önemlidir. Uzun dönemde ekonomik küreselleşme Brezilya, Çin, Hindistan ve Güney Afrika'da iktisadi büyümeyi pozitif yönlü etkilemiştir. Başka bir ifadeyle bu ülkelerin ekonomik küreselleşme süreçleri ekonomik kalkınmalarını olumlu etkilemiştir. Ancak Endonezya, Malezya, Meksika, Filipinler ve Tayland ile Türkiye'de ekonomik küreselleşme ve iktisadi büyüme arasında herhangi bir uzun dönem nedensellik ilişkisi bulunmamıştır.

Araştırma ülkelerinde kısa dönemde meydana gelen şokların üç dönem sonra dengeye geldiği görülmüştür. Buna göre, dış borçlar kısa dönemde Brezilya, Hindistan, Endonezya, Güney Afrika, Tayland ve Türkiye'de iktisadi büyümeyi negatif yönlü etkilemiştir (borç fazlası teorisi doğrulanmaktadır). Çin, Malezya, Meksika ve Filipinler'de ise kısa dönemde dış borçların iktisadi büyüme ile arasında herhangi bir nedensellik ilişkisine sahip olmadığı görülmüştür. Kısa dönemde ekonomik küreselleşme ile iktisadi büyüme arasında ise herhangi bir nedensellik ilişkisi bulunmamıştır. Buna göre NIC ülkelerinde ekonomik küreselleşmenin kalkınma düzeyi üzerindeki etkisi uzun dönemde ortaya çıkmaktadır.

\section{KAYNAKLAR}

Adamu, İ.M. \& Rasiah, R. (2016). External Debt and Growth Dynamics in Nigeria. African Development Review, 28(3),291-303. https://doi.org/10.1111/14678268.12206

Akan, Y. ve Kanca, O.C. (2015). Türkiye'de Dış Borçlanma, Büyüme ve Enflasyon Yaklaşımı (1980-2013). Hacettepe Üniversitesi İktisadi ve İdari Bilimler Fakültesi Dergisi, 33(3), 1-22. 
Akram, N. (2015). Is Public Debt Hindering Economic Growth Of The Philippines? Internatıonal Journal of SocialEconomics, 42(3), 201-221. Doi:10.1108/IJSE02-2013-0047

Bilginoğlu, M. İ. \&Aysu, A. (2008). Dış Borçların Ekonomik Büyüme Üzerine Etkisi: Türkiye Örneği. Erciyes Üniversitesi İktisadi ve İdari Bilimler Fakültesi Dergisi, 31, 1-23.

Bilginoğlu, M.A. \& Aysu, A. (2008). Dış Borçların Ekonomik Büyüme Üzerindeki Etkisi: Türkiye Örneği. Erciyes Üniversitesi İktisadi ve İdari Bilimler Fakültesi Dergisi, 31, 1-23.

Bittencourt, M. (2015). Determinants of Government and External Debt: Evidence from the Young Democracies of South America. Emerging Markets Finance \&Trade, 51, 463-472. https://doi.org/10.1080/1540496X.2015.1025667

Butts, H., C. Dr. Ivor Mitchell \& Albert B. (2012). Economic Growth Dynamics and ShortTerm External Debt In Thailand, The Journal of Developing Areas, 46(1), 91-111.

Cohen, D. (1993). Low Investment and Large LDC Debt in the 1980s, The American Economic Review, 83(3), 1993, 437-449.

Çöğürcü, İ.\& Çoban, O. (2011). Dış Borç Ekonomik Büyüme İlişkisi: Türkiye Örneği (1980-2009). KMÜ Sosyal ve Ekonomik Araştırmalar Dergisi, 13(21), 133149.

Diamond, P. A. (1965). National Debt İn Neoclassical Growth Model, The American Economic Review, 55 (5), 1126-1150.

Donayre, L. \& Taivan, A. (2017). Causality between Public Debt and Real Growth in the OECD: A Country-by-country Analysis, Economic Paper, 36(2), 156-170. https://doi.org/10.1111/1759-3441.12175

Duran, M.G.G. (2017). Public Debt and Economic Growth In The Philippines: Evidence of Causality, 20. International Scientific Conference " Economic and Social Development", 267-280.

Easterly, W. (1999). How did Highly Indebted Poor Countries Become Highly Indebted? Reviewing Two Decades of Debt Relief, World Bank, September.

Eberhardt, M. \& Presbitero, A.F. (2015), Public Debt and Growth: Heterogeneity and non- linearity, Journal of International Economics, 97, 45-58. https://doi.org/10.1016/j.jinteco.2015.04.005

Esener, S. Ç. (2013). Gelişmekte Olan Ülkelerde ve Türkiye'de Dış Borçlanmanın İktisadi ve Mali Yapı Üzerindeki Etkileri (1980-2010). Yönetim ve Ekonomi Araştırmaları Dergisi, 19, 20-41. 
Guei, K.M. (2019). External Debt and Growth in Emerging Economies, International Economic Journal, 32(2), 236-251. https://doi.org/10.1080/10168737.2019.1590727

Gunter, B. G. (2002). What's Wrong witht he HIPC Initiative and What's Next? Development Policy Review, 20(1), 5-24. SSRN: https://ssrn.com/abstract=308970

Gül, E., Kamacı, A. \&Konya, S. (2012). Dış Borcun Büyüme Üzerine Etkileri: Orta Asya Cumhuriyetleri ve Türkiye Örneği. Internatıonal Conference on Eurasian Economies.

Gürdal, T. \& Yavuz, H. (2015). Türkiye'de Dış Borçlanma- Ekonomik Büyüme İlişkisi: 1990-2013 Dönemi. Maliye Dergisi, 168, 154-169.

Hjertholm, P., Laursen, J. \& Fellow White, H. (1998). Macroeconomic Issues İn Foreign Aid, Lessons of Experience and Directions for the Future, Institute of Economics, University of Copenhagen.

Işık, H. (2017). Devlet Borçları Ekonomik Büyümeyi Nasıl Etkiler? Bazı Değerlendirmeler. Hukuk ve İktisat Araştırmalart Dergisi, 9(2), 117-133. ISSN: 2146-0817

Kamacı, A. (2016). Dış Borçların Ekonomik Büyüme ve Enflasyon Üzerine Etkileri: Panel Eşbütünleşme ve Panel Nedensellik Analizi. Special Issue on theProceedings of the 5th ISCS Conference, 165-175.

Kasidi, F. \& Said, M. (2013). Impact of External Debt on Economic Growth: A Case Study of Tanzania. Advances in Management \& Applied Economics, 3(4), 2013, 59-82. ISSN: 1792-7544

Khemais, Z., Mohammed, M. \& Nesrine, D. (2016). External Debt \& Economic Growth: Case of Tunusia. International Journal of Economics and Finance, 8(6), 129-140. DOI:10.5539/ijef.v8n6p129

URL-1, https://www.kof.ethz.ch/en/forecasts-and-indicators/indicators/kof-

globalisation-index.html , (Erişim Tarihi: 9 Eylül 2018)

Krugman, P. (1988). Financing Vs. Forgiving a Debt Overhang, NBER Working Paper Series No: 2486.

Kutlu, S. \& Yurttagüler, İ. M. (2016). Türkiye'de Dış Borç ve Ekonomik Büyüme İlişkisi:1998-2014 Dönemi için Bir Nedensellik Analizi. Marmara Üniversitesi İktisadi ve İdari Bilimler Dergisi, 38 (1), 229-248.

Lin, S., K. Sosin (2001), Foreign Debt and Economic Growth, Economics of Transition, 9(3), 635-655.

Marobhe, M. (2019). External Debts and Economic Growth in Tanzania, Review of Integrative Business and Economic Research, 8(1), 64-79. 
Mohammed, E.S.E. (2018). Effect of External Debt on Economic Growth of Sudan: Empiricial Analysis (1969-2015), Journal of Economic Cooperation and Development, 39, 1 (2018), 39-62.

Moore, W. \& Thomas, C.(2013). A meta-analysis of the relationship between debt and growth, International Journal of Development, 9(3), 214-225. Doi: 10.1108/14468951011073307

Mosley, P., Hudson, J. \& Horell, S. (1987). Aid, The Public Sector And The Market İn Less Developed Countries, The Economic Journal, 97, 616- 641.

Nelasco, S. (2012). An Economic Analysis on the External Debt Burdenof South Asian Countries, Journal of Educational and Social Research, 2(9), 11-22. Doi:10.5901/jesr.2012.v2n9p11

Nissanke, M. \& Benno F. (2001). Debt Dynamics And Contingency Financing: Theoretical Reappraisal Of The Hipc Initiative, Wider Development Conference On Debt Relief, Helsinki.

Panizza, U., \& Presbitero, A. F. (2014). Public debt and economic growth: Is there a causal effect? Journal of Macroeconomics, 41, 21-41. https://doi.org/10.1016/j.jmacro.2014.03.009

Pattillo, C., Poirson, H. \& Ricci, L. (2002). External Debt and Growth. Finance and Development, 39, 32-36.

Presbitero, A.F. (2008). The Debt-Growth Nexus in Poor Countries: A

Reassessment, Economics: The Open-Access, Open-Assessment E-Journal, 2: 1-28. http://dx.doi.org/10.5018/economics-ejournal.ja.2008-30

Reinhart, C.M. \& K. S. Rogoff (2010). Growth in a Time of Debt. American Economic Review: Papers \& Proceedings 100, 573-578. doi=10.1257/aer.100.2.573

Sachs, J. (1989). The Debt Overhang of Developing Countries, Debt, Stabilization and Development içinde, Calvo, G., Findlay, R., Kouri, P., Braga de Macedo, J., (der.), Basil Blackwell, Oxford, 80-102.

Tatoğlu, F. Y. (20170). Panel Zaman Serileri Analizi. İstanbul: Beta Basım Yayın Dağıtım.

Uzun, M., Karaköy, Ç., Kabaday1, B. \& Emsen, Ö.S. (2012). The Impacts of External Debt on Economic Growth in Transition Economies. Chinese Business Review,11(5), 491-499.

\section{URL-2,}

https://tr.wikipedia.org/wiki/Yeni sanayile\%C5\%9Fen \%C3\%BClkel er, (Erişim Tarihi:8 Ekim 2019) 
URL-3, https://www.worldbank.org/, (Erişim Tarihi: 9 Eylül 2018)

Zouhaier,H. \& Fatma, M. (2014). Debt and Economic Growth. International Journalof Economics and Financial Issues, 4, 440-448. ISSN: 2146-4138 